\title{
Physical indicators after mechanical scarification in a Yellow Oxisol under no-tillage
}

\section{Indicadores físicos após escarificação mecânica em um Latossolo Amarelo sob plantio direto}

\section{Luís Alfredo Pinheiro Leal NUNES ${ }^{1}$; Bruno Karvand Ferreira SOARES ${ }^{2}$; Ricardo Silva de SOUSA ${ }^{3}$; Thiago Vinicius Barros IBIAPINA ${ }^{4}$; Leovânio Rodrigues BARBOSA ${ }^{5}$}

\author{
${ }^{1}$ Autor para Correspondência: Doutor em Solos e Nutrição de Plantas, Docente do Departamento de Engenharia Agrícola e \\ Solos pela Universidade Federal do Piauí, Teresina-PI, luisalfredo@ufpi.edu.br \\ ${ }^{2}$ Mestre em Agronomia pela Universidade Federal do Piauí (UFPI), bruno.karvand4@gmail.com \\ ${ }^{3}$ Doutor em Agronomia (Agricultura Tropical), Docente do Departamento de Engenharia Agrícola e Solos pela Universidade \\ Federal do Piauí, Teresina-PI, ricardoss@ufpi.edu.br \\ ${ }^{4}$ Doutor em Agronomia (Ciência do Solo) pela Universidade Estadual Paulista Júlio de Mesquita Filho, Jaboticabal-SP, \\ ibiapina.thiago@gmail.com \\ ${ }^{5}$ Doutorando no Programa de Pós-graduação em Ciência do Solo, Areia, PB, leovaniobarbosa@hotmail.com
}

Recebido em: 23-06-2020; Aceito em: 25-09-2020

\begin{abstract}
Scarification improves soil physical conditions, resulting in suitable conditions for root growth in crops and water infiltration. This study evaluates the effects of mechanical scarification on the physical attributes of a Yellow Oxisol cultivated with soybean under no-tillage in the Savanna of Piauí state, Brazil. Three areas under soybean cultivation were chosen, namely: one in the second year of cultivation under no-tillage (CS2); one cultivated for ten years under no-tillage (CS10); one area with soybeans identical to the previous one, but with scarification for a year (ESC); and a native Savana vegetation (CV), used as control. Density, macroporosity, microporosity, total porosity, and soil resistance to penetration at depths between $0-0.20$ and $0.20-0.40 \mathrm{~m}$ were evaluated. The CS area showed decreased physical indicator values compared to the other management systems. Scarification was efficient in improving soil density, total porosity, and soil resistance to penetration at depths between 0.00 and $0.20 \mathrm{~m}$. CS2 and $\mathrm{CV}$ areas showed more favorable physical indicator values. Through multivariate analyses, it was possible to identify which physical variables correlated with each type of soil management and the effects of these managements on the physical characteristics of the soil studied.
\end{abstract}

Additional keywords: Soil compaction; soy; Cerrado.

\section{Resumo}

A escarificação melhora as condições físicas do solo, resultando em condições adequadas ao crescimento radicular das culturas e a infiltração da água. Objetivou-se neste trabalho avaliar os efeitos da escarificação mecânica nos atributos físicos de um Latossolo Amarelo cultivado com soja em plantio direto no Cerrado piauiense. Foram escolhidas três áreas sob cultivo com soja, sendo uma no segundo ano de cultivo sob plantio direto (CS2), uma cultivada há dez anos sob plantio direto (CS10) e uma área com soja idêntica à anterior, mas que sofreu escarificação há um ano (ESC), além de uma mata nativa de cerrado preservada (MN), que foi usada como controle. Avaliaram-se a densidade, macroporosidade, microporosidade e porosidade total, e a resistência do solo à penetração, nas camadas de 0-0,20 e 0,20-0,40 m. A área CS mostrou valores de indicadores físicos inferiores em relação aos demais sistemas de manejo. A escarificação foi eficiente em melhorar os valores de densidade do solo, porosidade total e resistência do solo à penetração na camada de 0,00 a $0,20 \mathrm{~m}$. As áreas CS2 e MN apresentaram valores de indicadores físicos mais favoráveis. Por meio das técnicas de análise multivariadas, foi possível identificar quais variáveis físicas estudadas se correlacionaram com cada tipo de manejo do solo adotado e os efeitos desses manejos sob as características físicas do solo estudado.

Palavras-chave adicionais: Compactação do solo; soja; cerrado.

\section{Introduction}

The replacement of Savanna vegetation by continuous cultivation of monoculture under conventional management, in general, causes drastic changes in soil physical quality and losses of organic matter content (Vezzani \& Mielniczuk, 2011). In turn, the no-tillage system (NT) is characterized as a conservationist management, supporting the maintenance of the soil cover and minimal disturbances that allow increased entry of organic carbon, favoring microbial activity and soil quality (Souza et al., 2019).

However, from the physical point of view, the absence of soil revolving and traffic of agricultural 
machines in the NT system forms compacted areas in the soil surface layer over time, reducing its physical quality and affecting crop development (Domit et al., 2014). Cortez et al. (2019), who studied the effect of the no-tillage system on soil physical attributes, observed intermediate and critical values of soil resistance to penetration. Nunes et al. (2015) stated that machine traffic and the absence of revolving in a no-tillage system causes serious problems to soil physical properties, inducing compaction.

Soil compaction is a phenomenon that interferes directly with the soil structure, resulting in decreased macropores, increased soil resistance to penetration and, consequently, decreased root development (Cunha et al., 2012; Moura et al., 2019). Thus, scarification has been recommended in several studies to reduce compaction in the soil surface layer in areas under no-tillage. Scarifying equipment is used in this type of management, which acts in a localized way, with less capacity of revolving layers and being less aggressive to the soil structure (Cortez et al., 2011). This mechanical practice minimizes compaction, as it reduces soil density (Nagahama et al., 2016) and soil resistance to penetration (Giacomeli et al., 2016), besides increasing macroporosity and total porosity (Fin et al., 2018).

Research by Nunes et al. (2015), who studied the effect of soil scarification on root structure and growth in a clayey soil under no-tillage, found that mechanical scarification contributed to improve soil physical attributes (resistance to penetration, macroporosity, and apparent density) and root development (root density). Seki et al. (2015), who studied the effect of soil decompaction in a no-tillage system, also reported benefits from scarification and subsoiling on soil physical attributes, with effect on crop development and yield.

Thus, this study evaluates the effects of mechanical scarification on the physical attributes of a Yellow Oxisol cultivated with soybean in the agricultural frontier of the Savanna of Piauí state, Brazil.

\section{Material and methods}

The study was carried out at Chapada Grande farm, located in the municipality of Regeneração, Piauí (06 ${ }^{\circ} 14^{\prime} 16^{\prime \prime} \mathrm{S}$ latitude and $42^{\circ} 41^{\prime} 18^{\prime \prime} \mathrm{W}$ longitude). This region has an average annual temperature of $32^{\circ} \mathrm{C}$ and average annual rainfall of $1,350 \mathrm{~mm}$, with rainfall distributed from January to May (Equatorial Continental Regime, with annual isohyets between 800 and $1,400 \mathrm{~mm})$. The climate, according to the Köppen climate classification, is of the type Aw'. The soil is classified as Yellow Latosol (Barbosa et al., 2016).

Four areas were selected. Three areas were cultivated with soybeans and one area was a preserved native vegetation, which was used as control (Table 1). In each area, four 200- $\mathrm{m}^{2}$ plots were demarcated, where four soil samples were collected at depths of 0.00-0.20 and 0.20-0.40 $\mathrm{m}$ in January 2017 for physical analysis.

Table1 - History and description of the management systems studied.

Management system and soil use

Description

Area in the second year of cultivation, where rice was

Area with two years of cultivation (CS2) cultivated in the first year and soy was cultivated in the following year. Fertilization and liming were applied based on the recommendation of soil analysis for soybean culture.

Area in the tenth year of cultivation, where rice was cultivated in the first year and soybean was cultivated from the second to the sixth year under conventional Area with ten years of cultivation (CS10) management using plow and harrow. From the seventh year on, only soybeans were cultivated, without off-season. Fertilization and liming identical to the aforementioned was carried out based on the recommendation for soybean crop.

Area with ten years of use. Management was identical to CS10 until the ninth year. However, scarification was carried

Area with ten years of scarified cultivation (ESC) out at a depth of $0.18 \mathrm{~cm}$ with a scarifier with five rods spaced $0.30 \mathrm{~m}$ apart and a ripper roller, in the previous year, with the soil characterized by friable consistency.

Native vegetation area (NV)

Native Forest of the Savanna Biome, with predominance of the following species: Genipa americana, Hymenaea stigonocarpa, Caryocar brasiliense. 
Granulometric analysis (Table 2) was performed by the pipette method. Total soil porosity (TP), macroporosity (Map), and microporosity (Micro) were determined with undisturbed samples by suction table. Soil density (Sd) was determined by volumetric ring and aggregate stability was performed in a vertical shaker with sets of sieves with meshes of $2.0 ; 1.0 ; 0.5 ; 0.25$, and $0.105 \mathrm{~mm}$ apertures (EMBRAPA, 2017). Organic carbon (CO) was analyzed by wet method, according to Yeomans \& Bremner (1988).

Table 2 - Soil granulometric composition in the management systems studied.

\begin{tabular}{lcccc}
\hline \multirow{2}{*}{ Soil system management } & \multicolumn{3}{c}{ Granulometry $\left(\mathrm{g} \mathrm{kg}^{-1}\right)$} & \multirow{2}{*}{ Texture class } \\
\cline { 2 - 4 } CS2 & Sand & Silt & Clay & \\
CS10 & 370 & Depth $(0.00-0.20 \mathrm{~m})$ & & Clayey \\
ESC & 343 & 203 & 427 & Clayey \\
NV & 335 & 220 & 438 & Clayey \\
& 367 & 215 & 440 & Clayey \\
CS2 & & Depth $(0.20-0.40 \mathrm{~m})$ & 428 & \\
CS10 & 360 & 170 & 470 & Clayey \\
ESC & 337 & 216 & 447 & Clayey \\
NV & 342 & 208 & 450 & Clayey \\
\hline
\end{tabular}

CS2 = two-year-old soybean cultivation area; CS10 = ten-year-old soybean cultivation area; ESC = ten-year-old soy cultivation area that underwent scarification a year ago; NV = area under native Savanna vegetation.

Soil resistance to penetration (SRP) was determined with gravimetric moisture, ranging from 20 to $24 \%$ up to the 0.40-m layer (Table 3) using an impact penetrometer (model IAA / Planalsucar-Stolf) (Stolf, 1991).

Table 3 - Gravimetric soil moisture in the studied management systems.

\begin{tabular}{cccccc}
\hline Depth & CS2 & CS10 & ESC & NV & Average \\
\cline { 2 - 6 }$(\mathrm{m})$ & $---\cdot-\cdot-{ }^{2}$ & 24.10 & 24.25 & 24.80 & 24.4 \\
\hline $0.00-0.20$ & 24.45 & 20.20 & 21.15 & 22.90 & 21.6 \\
$0.20-0.40$ & 22.15 & &
\end{tabular}

CS2 = two-year-old soybean cultivation area; CS10 = ten-year-old soybean cultivation area; ESC $=$ ten-year-old soy cultivation area that underwent scarification a year ago; NV = area under native Savanna vegetation.

Resistance values were calculated from a depth of $0.05 \mathrm{~m}$. From the values obtained, layers were discriminated with respect to their degree of compaction, according to the USDA protocol (USDA, 1993), with a limit of $2 \mathrm{MPa}$ considered as a strong restriction to root growth. The weighted mean diameter (WMD) and aggregate stability index (ASI) were obtained according to Castro Filho et al. (1998).

The data were submitted to analysis of variance by $F$ test and analyzed in a completely randomized experimental design. Mean comparison was performed using the Tukey test at $5 \%$. In addition, Principal Component Analysis (PCA) was used to reduce data dimensions and, consequently, facilitate the interpretation of soil patterns in relation to the data obtained. PCA was processed with the correlation matrix of the original variables, which built the eigenvectors, processed in the R program (R Core Team, 2016).

\section{Results and discussion}

Soil density $(\mathrm{Sd})$ in the studied areas ranged between 0.90 and $1.16 \mathrm{Mg} \mathrm{m}^{-3}$ for the $0.00-0.20 \mathrm{~m}$ layer and between 0.96 and $1.27 \mathrm{Mg} \mathrm{m}^{-3}$ for the $0.20-0.40 \mathrm{~m}$ layer (Table 4). The CS10 surface layer had the highest Sd value, while ESC had an intermediate value. On the other hand, in the $0.20-0.40 \mathrm{~m}$ layer, CS10 and ESC treatments did not differ, with values close to the upper limit of $\mathrm{Sd}$, which is $1.30 \mathrm{Mg} \mathrm{m}^{-3}$ for clayey soils (Reynolds et al., 2007), after which there will be restrictions for root growth and plant development. This shows that the effect of the scarifier occurred only in the surface layer, where compression is more intense in notillage, demonstrating the effectiveness of this mechanical practice to minimize this limiting factor for crop yield, as also observed by Klein \& Klein (2015). Macroporosity reduced in the surface layer $(0.20 \mathrm{~m})$ in tCS10 and ESC management systems. The observed result is probably linked to the history of these areas, worked on conventional management for six years. As of 2013, that is, four years before the study, soil management was changed to no-tillage. Thus, it is likely that there was not enough time for improvements in this variable. In the $0.20-0.40 \mathrm{~m}$ layer, no statistical differences were observed in the Map values between areas under management and native vegetation.

A study by Moraes et al. (2016) found that the conventional planting system for 20 years in a clayey Red Latosol increased soil density and reduced macroporosity in the $0.20 \mathrm{~m}$ layer to values below critical for crop development in relation to no-tillage. According 
to the authors, soil physical quality improves over time after adopting no-tillage. For Dal Ferro et al. (2014), conventional planting contributes to soil pulverization, leading to less macroporosity in the surface layer in relation to no-tillage. Map values are important for the quick flow of water and air in the soil and for diagnosing soil compaction, since the main reduction in soil pore volume occurs in this fraction of total porosity (Schjonning \& Lamande, 2010).

Table 4 - Soil density (SD), total porosity (TP), macroporosity (Map), microporosity (Mip), weighted average diameter (WAD), aggregate stability index (ASI), and total organic carbon (TOC) at two depths of the soil in the management systems studied.

\begin{tabular}{|c|c|c|c|c|c|c|c|}
\hline \multirow[t]{2}{*}{ Treatment } & $\begin{array}{c}\mathrm{SD} \\
\left(\mathrm{Mg} \mathrm{m}^{-3}\right)\end{array}$ & Map & $\begin{array}{c}\text { Mip } \\
-\left(m^{3} m^{-3}\right)\end{array}$ & $\begin{array}{c}\text { TP } \\
----\end{array}$ & $\begin{array}{l}\text { WAD } \\
(\mathrm{mm})\end{array}$ & $\begin{array}{l}\text { ASI } \\
(\%)\end{array}$ & $\begin{array}{c}\text { TOC } \\
\left(\text { dag kg }^{-1}\right)\end{array}$ \\
\hline & & & & $0.00-0.20 \mathrm{~m}$ & & & \\
\hline CS2 & $0.90 \mathrm{c}$ & $0.25 b$ & $0.39 a$ & $0.63 \mathrm{a}$ & $1.00 \mathrm{~b}$ & $0.67 \mathrm{~b}$ & $2.42 \mathrm{a}$ \\
\hline CS10 & $1.16 \mathrm{a}$ & $0.16 \mathrm{c}$ & $0.35 a$ & $0.51 \mathrm{c}$ & 0.72 b & $0.49 \mathrm{~b}$ & $2.00 \mathrm{~b}$ \\
\hline ESC & $1.04 \mathrm{~b}$ & $0.19 \mathrm{c}$ & $0.39 a$ & $0.58 \mathrm{~b}$ & $1.02 \mathrm{~b}$ & $0.64 \mathrm{~b}$ & $2.18 \mathrm{ab}$ \\
\hline \multirow[t]{2}{*}{ NV } & $0.91 \mathrm{c}$ & $0.34 \mathrm{a}$ & $0.30 \mathrm{~b}$ & $0.63 \mathrm{a}$ & $1.56 \mathrm{a}$ & $1.04 \mathrm{a}$ & $2.52 \mathrm{a}$ \\
\hline & & & & $0.20-0.40 \mathrm{~m}$ & & & \\
\hline CS2 & $0.96 \mathrm{c}$ & $0.30 \mathrm{a}$ & $0.31 \mathrm{a}$ & $0.61 \mathrm{a}$ & $1.05 a b$ & $0.71 \mathrm{~b}$ & $1.50 \mathrm{~b}$ \\
\hline CS10 & $1.27 \mathrm{a}$ & $0.25 a$ & $0.23 \mathrm{~b}$ & $0.48 \mathrm{c}$ & $0.79 b$ & $0.51 \mathrm{~b}$ & $1.48 b$ \\
\hline ESC & $1.23 \mathrm{a}$ & $0.32 \mathrm{a}$ & $0.18 b$ & $0.50 \mathrm{c}$ & $1.22 \mathrm{a}$ & $0.81 \mathrm{~b}$ & $1.44 \mathrm{~b}$ \\
\hline NV & $1.06 \mathrm{~b}$ & $0.33 \mathrm{a}$ & $0.24 \mathrm{~b}$ & $0.57 \mathrm{~b}$ & $1.31 \mathrm{a}$ & $0.85 a$ & $1.90 \mathrm{a}$ \\
\hline
\end{tabular}

CS2 = two-year-old soybean cultivation area; CS10 = ten-year-old soybean cultivation area; ESC = ten-year-old soy cultivation area that underwent scarification a year ago; NV = area under native Savanna vegetation. Averages followed by the same letter in the column do not differ by Tukey test $(p>0.05)$.

In table 4 also shows that soybean cultivation did not interfere with microporosity $(\mathrm{Mi})$ in the $0.0-0.20$ $\mathrm{m}$ layer. The observed result is probably due to the pores related to soil texture, especially clay and silt levels, that were similar between the areas evaluated, as also evaluated by Lima et al. (2014). In the subsurface layer, Mi was significantly higher in the CS2 area, possibly due to higher clay content in this layer.

The highest values of total porosity (TP) in the depths studied were observed in the NV and CS2 areas. Barbosa et al. (2016), who studied the chronosequence of conventional management in soybean crops, also found higher TP in newly explored areas under native vegetation, compared to areas with longer management time. In relation to areas with a longer history of management, the result observed for ESC in the superficial layer indicates that scarification can be an alternative to improve the porosity of a soil that has been managed for a certain time in a conventional manner. Giacomeli et al. (2016) found an increase of $18 \%$ in total porosity and $58 \%$ in macroporosity after scarification of a compacted soil.

Regarding weighted mean diameter (WMD) and aggregate stability index (ASI), the area with NV was superior to the other areas at $0-0.20$ and $0.20-0.40$ $\mathrm{m}$ depths (Table 4). Generally, native forest soils have more organic matter and greater aggregate stability (Secco et al., 2005) due to increased input and diversity of organic residues without interference from any cultivation form. In this study, higher values of organic carbon, (indicators of organic matter) were observed in the area of native forest and in CS2 (Table 4). In management systems with intense soil moving for several years, as occurred for six years in the CS10 and ESC areas, aggregates are destroyed, reducing ASI
(Sousa Neto et al., 2008).

Research carried out in areas of the Savana of Piauí showed that intense soil revolving with the combination of plowing and harrowing, as to create favorable physical conditions to the development of soybean roots, compromised the stability of aggregates and reduced WMD (Ibiapina et al., 2014; Araújo et al., 2010). In figure 1 shows that the CS10 area expressed higher soil resistance to penetration ( $3.81 \mathrm{MPa})$ up to a depth of $0.20 \mathrm{~m}$, which is generally more affected by different soil managements, compared to other treatments. Marasca et al. (2011), who analyzed the SRP of a Dystrophic Red Oxisol cultivated under notillage for 13 years, found mean SRP values ranging between $2.9 \mathrm{MPa}$ and $4.2 \mathrm{MPa}$, with moisture contents between 0.13 and $0.25 \mathrm{~kg} \mathrm{~kg}^{-1}$ in the $0.0-0.20 \mathrm{~m}$ layer. This can be explained by machine traffic over the years during agricultural operations, causing damage to the soil physical structure, consequently reducing porous space and resulting in soil compaction.

On the other hand, in the ESC system, the soil showed values of less than $2.00 \mathrm{MPa}$ in the layer close to $10 \mathrm{~cm}$, which fits in the moderate class according to USDA (1993). This shows the positive effect of the 18$\mathrm{cm}$ rod scarifier in this $0-20 \mathrm{~cm}$ layer, even twelve months after this practice. Research by Girardello et al. (2014) and Drescher et al. (2016) in a clayey Red Latosol under long-term no-tillage observed that scarification significantly reduced soil resistance to penetration, creating more favorable conditions for plant root development. On the other hand, NV and CS2 systems, more preserved, had the lowest SRP values, ranging between 0.75 and $2.08 \mathrm{MPa}$ in all depths studied, which fits them in the low and moderate resistance range. 


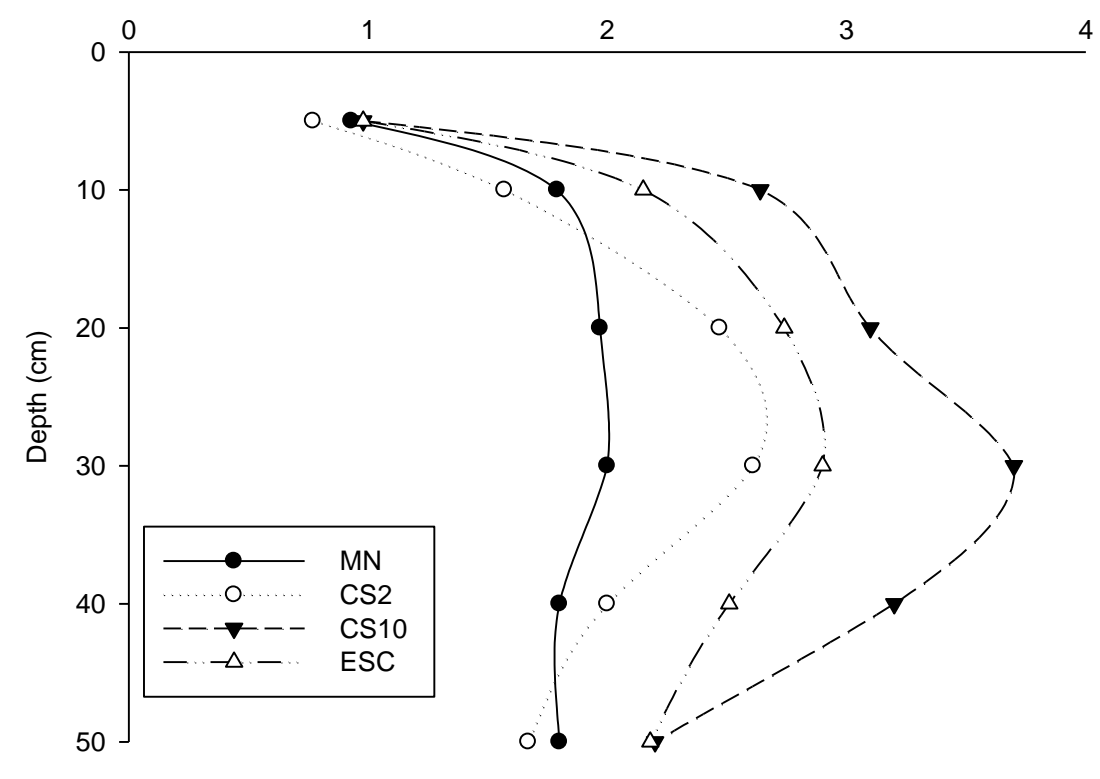

Figure 1 - Soil resistance to vertical soil penetration in the studied management systems.

CS2 = two-year-old soybean cultivation area; CS10 = ten-year-old soybean cultivation area; ESC = ten-year-old soy cultivation area that underwent scarification a year ago; NV = area under native Savanna vegetation.

Soil density (SD), total porosity (TP), macroporosity (Map), microporosity (Mip), weighted average diameter (WAD), aggregate stability index (ASI), and total organic carbon (TOC) at two depths of the soil in the management systems studied.

Principal component analysis (PCA) was performed on the data matrix consisting of seven variables (Figure 2). Regarding the percentage of variance explained by the principal component analysis, it appears that the first two principal components account for $88 \%$ of the original variability, with $\mathrm{CP} 1$ and $\mathrm{CP} 2$ retaining $52.2 \%$ and $35.8 \%$, respectively. According to the multivariate analysis, variation in the efficiency of treatments at both depths was observed, and it was possible to identify which variables correlated more with each management type and the effects on changes in soil characteristics.

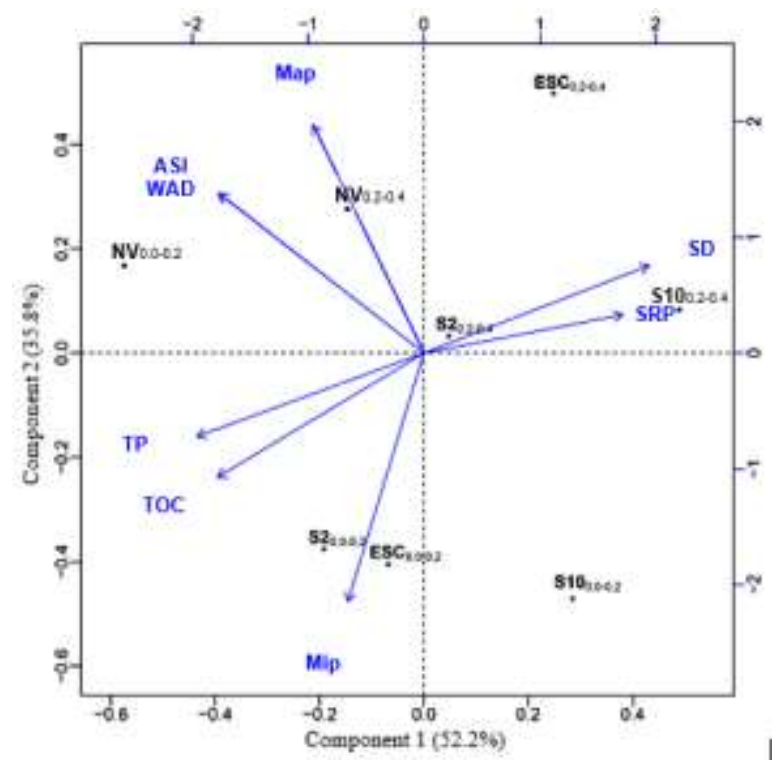

Figure 2 - Main components ( 1 and 2) based on the soil variables of the different areas studied at two depths (0.0$0.20 \mathrm{~m}$ and $0.20-0.40 \mathrm{~m}$ ).

CS2 = two-year-old soybean cultivation area; CS10 = ten-year-old soybean cultivation area; ESC = ten-year-old soy cultivation area that underwent scarification a year ago; NV = area under native Savanna vegetation. 
It is observed that NV, in the two depths studied (0.0-0.20 and 0.20-0.40 m), formed an isolated group, positioned in the upper left quadrant. This group was better correlated with ASI, WMD, and Map variables. This occurs due to higher $\mathrm{CO}$ content (Table 4) from organic residue in these systems, which contributes to a better soil structure, favoring the values of these variables.

The CS10 area at a 0.20-0.40 m depth was positioned in the upper right quadrant and was more associated with Sd and SRP variables, since this area was managed for a long time in conventional planting followed by no-tillage, whose mobilization absence and machine traffic causes compaction in the subsurface layer (Moraes et al., 2020), providing higher values of Sd and RP variables. The CS2 and ESC areas, at a depth of $0.20-0.40 \mathrm{~m}$, are also included in the same quadrant. However, they did not correlate with any variable.

In turn, CS2 and ESC areas at 0.00-0.20 m depth showed similarity and were positioned in the lower left quadrant, being more correlated to the micro variable in relation to the other areas studied.

\section{Conclusions}

The no-tillage system for ten years showed values of physical indicators that indicate soil compaction.

Scarification was efficient to improve the values of soil physical quality indicators in the layer between 0.00 and $0.20 \mathrm{~m}$.

The multivariate analyses identified which physical variables correlated with each soil management type and the effects of these managements on the physical characteristics of the soil studied.

\section{Acknowledgment}

To the National Council for Scientific and Technological Development (CNPq) for granting financial support to the research of the second author.

\section{References}

Araújo FS, Salviano, AAC, Leite LFC, Souza ZM, Sousa ACM (2010) Physical quality of a Yellow Latossol under integrated crop-livestock system. Revista Brasileira de Ciência do Solo 34(3):717-723.

Barbosa LR, Nunes LAPL, Araújo ASF, Silva FR, Ibiapina TVB (2016). Penetration resistance and density of a yellow oxissol under conventional management at different ages. Bioscience Journal, 32(1):115-122.

Cortez JW, Moreno CRT, Farinha LS, Arcoverde CNS, Valentes IQM (2019) Variabilidade espacial da resistência do solo à penetração em um sistema de semeadura direta. Revista Científica 47(2): 175-182.
Cortez JW, Alves ADS, Moura MRD, Olszevski N, Nagahama HJ (2011) Atributos físicos de um Argissolo amarelo do semiárido nordestino sob sistemas de preparo. Revista Brasileira de Ciência do Solo 35(4):1207-1216.

Cunha EQ, Stone LF, Ferreira, EPB, Didonet AD, Moreira JAA (2012) Atributos físicos, químicos e biológicos do solo sob produção orgânica impactadas por sistemas de cultivo. Revista Brasileira de Engenharia Agrícola e Ambiental 6(1):56-63.

Dal Ferro N, Sartori L, Simonetti G, Berti A, Morari F (2014) Soil macro and microstructure as affected by different tillage systems and their effects on maize root growth. Soil Tillage Research 140(1):55-65.

Domit LA, Okumura RS, Barbosa GMC, Higashibara LR, Dalbosco M, Mariano DC, Zorzenoni TO, Guimarães MF (2014) Tempo de adoção do sistema plantio direto e a relação com atributos do solo. Agrarian 7(26):560-569.

Dresche RMS, Eltz FLF, Denardin JE, Faganello A, Drescher GL (2016) Duração das alterações em propriedades físico-hídricas de Latossolo argiloso decorrentes da escarificação mecânica. Pesquisa Agropecuária Brasileira 51(2):159-168.

EMBRAPA (2017) Empresa Brasileira de Pesquisa Agropecuária (2017) Manual de métodos de análise de solo 3a․ ed. Rev. e Amp. Brasília, DF: Embrapa, 573 p.

Fin SS, Marchesan E, Gubiani PI, Farenzena JAP, Murari MS, Coelho LL, Cargnelutti Filho A, Aramburu BB (2018) Duration of the effects of scarification and raised bed associated with vegetation cover on soybean yield on an Alfisol. Pesquisa Agropecuária Brasileira 53(11):1230-1238.

Giacomeli R, Marchesan E, Sartori GMS, Donato G, Silva PF, Kaiser DR, Aramburu BB (2016) Escarificação do solo e sulcadores em semeadora para cultivo de milho em Planossolos. Pesquisa Agropecuária Brasileira 51(3):261-270.

Girardello VC, Amado TJC, Santi AL, Cherubin MR, Kunz J, Teixeira TG (2014) Resistência à penetração, eficiência de escarificadores mecânicos e produtividade da soja em Latossolo argiloso manejado sob plantio direto de longa duração. Revista Brasileira de Ciência do Solo 38(4):1234-1244

Ibiapina TVB, Salviano AAC, Nunes LAPL, Mousinho FEP, Lima MG, Soares LMS (2014) Resistência à penetração e agregação de Latossolo Amarelo sob monocultivo de soja e de eucalipto no cerrado piauiense. Científica 42(4):411-418. 
Klein C, Klein VA (2015) Least limit in water range under no-tillage system and maize grain yield. Científica 43(2):179-187.

Lima JRS, Souza ES, Antonino ACD, Silva IF, Corrêa MM, Lira CABO (2014) Atributos físico-hídricos de um Latossolo Amarelo cultivado e sob mata nativa no Brejo Paraibano. Revista Brasileira de Ciências Agrárias 9(4):599-605.

Marasca I, Oliveira CAA, Guimarães EC, Cunha JPAR, Assis RL, Perin A, Menezes, LAS (2011). Variabilidade espacial da resistência do solo à penetração e do teor de água em sistema de plantio direto na cultura da soja. Bioscience Journal 27(2):239-246.

Moraes MT, Debiasi, H, Franchini J, Mastroberti AA, Levien R, Leitner D, Schnepf A (2020). Soil compaction impacts soybean root growth in an Oxisol from subtropical Brazil. Soil Tillage Research 200(6)1-14.

Moraes MT, Debiasi H, Carlessoc R, Franchinib JC, Silva VR, Luz FB (2016) Soil physica lquality on tillage and cropping systems after two decades in the subtropical region of Brazil. Soil Tillage Research 155(1):351-362.

Moura JC, Barbosa MAB, Cardoso SS (2019) Interferência da compactação do solo no manejo de altas produtividades na cultura da soja. Nucleus, 16(1): 205213.

Nagahama HJ, Granja GP, Cortez JW, Ramos RL, Napoleão S, Arcoverde S. (2016) Efeitos da escarificação mecânica nos atributos físicos do solo e agronômicos do capim elefante. Revista Ceres 63(5): 741746.

Nunes MR, Denardin JE, Pauletto EA, Faganello A, Pinto LFS. (2015) Effect of soil chiseling on soil structure and root growth for a clayey soil under no-tillage. Geoderma 259 (1):149-155.

R Core Team R (2016) A Language and Environment for Statistical Computing. R Foundation for Statistical Computing. Vienna, Austria.
Reynolds WD, Drury CF, Yang XM, Fox CA, Tan CS, Zhang TQ (2007) Land management effects on the near-surface physical quality of a clay loam soil. Soil Tillage Residue 96(1-2):316-330.

Secco D, Da Ros CO, Secco JK, Fiorin JE (2005) Atributos físicos e produtividade de culturas em um Latossolo Vermelho argiloso sob diferentes sistemas de manejo. Revista Brasileira de Ciências do Solo 29(3):407-414.

Seki AS, Seki FG, Jasper SP, Silva PRA, Benez SH (2015) Effects of soil decompaction techniques in na area under a system of direct seeding. Revista Ciência Agronômica 46(3):460-465.

Schjonning P, Lamande M (2010) A note on the vertical stresses near the soil-tyre interface. Soil Tillage Research 108(1-2):77-82.

Sousa Neto EL, Andrioli I, Beutler AN, Centurion JF (2008) Atributos físicos do solo e produtividade de milho em resposta a culturas de pré-safra. Pesquisa Agropecuária Brasileira 43(2):255-260.

Souza ED, Silva CRM, Pinto FA, Carneiro MAC, Paulinho HB, Pacheco LP, Terra FD, Laroca JVS (2019) Soil quality indicators after conversion of "murundu" fields into no-tillage cropping in the Brazilian Cerrado. Pesquisa Agropecuária Brasileira, 54(1):1-9.

Stolf R (1991) Teoria e teste experimental de fórmulas de transformação dos dados de penetrômetro de impacto em resistência do solo. Revista Brasileira de Ciência do Solo 15(3):229-235.

USDA - United State Department Agriculture (1993) Soil survey manual. Washington:Soil Survey Division Staff. $437 p$.

Vezzani FM, Mielniczuk J. (2011) Agregação e estoque de carbono em Argissolo submetido a diferentes práticas de manejo agrícola, Revista Brasileira de Ciência do Solo, 35(1):213-223.

Yeomans JC, Bremner JM (1988) A rapid and precise method for routine determination of organic carbon in soil. Communications in Soil Science and Plant Analysis, 19(11):1467-1476. 